\title{
European Practice in Ensuring Sustainable Development: Problems and Contradictions
}

\author{
Submitted 15/05/20, 1st revision 08/06/20, 2nd revision 15/07/20, accepted 30/07/20 \\ T.S. Malakhova ${ }^{1}$, P.P. Kapustin ${ }^{2}$, S.A. Morusov ${ }^{3}$, E.E. Udovik ${ }^{4}$
}

\begin{abstract}
:
Purpose: The article aims to study the foreign economic relations of the European Union countries and to identify problems and contradictions arising within the integration process. It also suggests approaches in terms of their further cooperation in the light of the growing geo-economic imbalances.

Design/Methodology/Approach. In modern conditions, the problem of inequality between developed and developing countries of the European Union significantly affects the prospects for their medium-and long-term cooperation. In addition, the consequences of the first wave of the global crisis (2008-2011) did not allow the countries of the EU South to enter the growth path. On this basis, authors revealed a negative trend for the growth of public debt in almost all countries of the South within the EU, which could lead to destabilization of the entire integration process. As a theoretical and methodological basis, the article utilizes historicallogical, statistical, and comparative analysis, systemic and situational approaches for the study of foreign economic relations between the EU countries.

Findings: Four sectoral clusters in the European Union are identified that can use the 'consolidation of sectoral clusters' mechanism in practical terms. As the study shows, these approaches will help smoothing out economic inequality between developed and developing countries of the European Union.

Practical implications: Authors are considering the consistent application of horizontal and sectoral (industrial) approaches within the European Union, which will reduce inequality between the partner countries in the integration group.

Originality/value. Since economic contradictions lead to the transformation of the integration group in the short and medium term, it is necessary to develop new approaches and mechanisms for foreign economic cooperation between the partner countries.
\end{abstract}

Keywords: European Union, integration, cooperation, economic inequality, world economy. JEL Code: F02, F15, F63.

Paper type: Research article.

${ }^{1}$ Ph.D., Assistant Professor of the Chair of World Economy and Management, Kuban State University, Krasnodar; Doctoral Student of the World Economy Department of the

Plekhanov Russian University of Economics, Moscow, malakhovats@ mail.ru

${ }^{2}$ Applicant of the Department of management and marketing of Belgorod State University, Belgorod, Kapustin@mail.ru

${ }^{3}$ Applicant of the Department of management and marketing of Belgorod State University, Belgorod, morusov@mail.ru

${ }^{4}$ Doctor of Science (Pedagogy), Candidate of Science (Economy), Professor, Department of Economy and Management, Kuban State Technology Universiry, Krasnodar, udovik@mail.ru 


\section{Introduction}

Before the first wave of the current global economic crisis (2008-2011), foreign and Russian economists, as well as experts, enthusiastically spoke about the prospects for the development of the European Union. Then practically no one doubted that this integration group was approaching its final stage of integration i.e., the formation of a political union. However, the European Union at that time faced quite complex and even insoluble problems that still do not give the opportunity to develop steadily. Therefore, in modern conditions, the issue of creating new forms and mechanisms of foreign economic interaction between countries is actively discussed, based on the findings of scientists and experts. Ballasa (1982) in his research did not focus on the analysis of practical experience, but rather on the harmony of the logical construction of integration. It must be emphasized that the design presented remains the most developed version of regional economic integration in modern conditions.

If we study integration as a form of interaction between countries, in modern conditions it cannot be viewed in the same context. Separate integration groups, for example, ASEAN, MERCOSUR, saw integration as an opportunity to protect their national interests from the influence of the United States, Japan, and other countries. Western European countries had completely different goals for integration. First, they were interested in strengthening their economic positions in the world market, in cooperation between enterprises of partner countries, in reducing the cost of production of finished products, etc. This article explores the experience of interaction between countries of the European Union.

\section{Materials and Methods}

Foreign economic relations between countries were always the discussion point for scientists and academics. In addition, considering the evolution of international economic relations between partner countries, scientists developed various forms of interrelations such as integration, partnership, unions, organizations, etc. (Balassa, 1982; Weiner, 1953; Galbraith, 1951; Myrdal, 1956; Nehru, 1961; Pasos, 1953; Prebish, 1981; Sanchez, 1966; Tinbergen, 1952; Williams, 1953; Frank, 1980). Statistical and comparative analysis, systemic and situational approaches with their structural and functional research methods gained importance in grounding the need to develop forms and approaches in foreign economic relations between countries of the European Union. The use of these methods allowed the formation of horizontal and sectoral approaches in foreign economic relations between the countries of the Vanguard and the periphery within the EU.

\section{Results}

In modern conditions, the economic relations between the countries of the European Union are quite complex and contradictory. This is due primarily to increasing 
inequality between developed and developing countries in the integration group, different economic models that are formed in the countries of the European Union, etc. Of course, this fact leads to the transformation of the existing foreign economic relations and the instability of macroeconomic indicators. Table 1 presents the main macroeconomic indicators, key sectors and large companies of the EU member states for 2016-2018.

Table 1. Key macroeconomic indicators, key industries, and largest companies in the European Union for 2016-2018 (Compiled based on CIS\&EU, 2018; Eurostat, 2018)

\begin{tabular}{|c|c|c|c|c|c|c|}
\hline \multirow[b]{2}{*}{$\begin{array}{c}\text { EU member } \\
\text { countries }\end{array}$} & \multicolumn{5}{|c|}{$2016 / 2018$} & \multirow[b]{2}{*}{ Key industries and features of EU member states } \\
\hline & 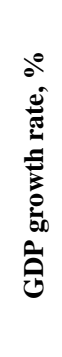 & 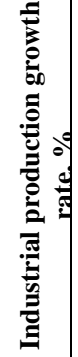 & : & 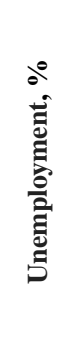 & 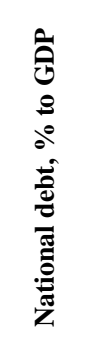 & \\
\hline Austria & $\begin{array}{l}1,4 / \\
2,8\end{array}$ & $\begin{array}{l}1,5 / \\
1,4\end{array}$ & $\begin{array}{l}1,0 / \\
2,2\end{array}$ & $\begin{array}{l}6,1 / \\
5,5\end{array}$ & $\begin{array}{l}85,8 / \\
78,5\end{array}$ & $\begin{array}{l}\text { Key industries: mechanical engineering, machine tool } \\
\text { industry, textile, leather and shoe, clothing, high } \\
\text { technology, etc. The service sector prevails (in } \\
\text { particular tourism). Major companies: Alcar heringrad } \\
\text { GMBH, AKG Acoustics GmbH, Atomic Austria } \\
\text { GmbH, etc. }\end{array}$ \\
\hline Belgium & $\begin{array}{l}1,4 / \\
1,5\end{array}$ & $\begin{array}{l}1,5 / \\
1,5\end{array}$ & $\begin{array}{l}1,8 / \\
2,2\end{array}$ & $\begin{array}{l}8,4 / \\
7,1\end{array}$ & $\begin{array}{l}106,7 / \\
103,4\end{array}$ & $\begin{array}{l}\text { Key industries: mechanical engineering (power, car } \\
\text { assembly, electronic, etc.), agriculture, tertiary sector } \\
\text { etc. Major companies: KBC Group, BDO, Proximus, } \\
\text { Saluc SA, Septentrio, Sibélco Group, etc. }\end{array}$ \\
\hline Bulgaria & $\begin{array}{l}3,9 / \\
3,6\end{array}$ & $\begin{array}{l}2,8 / \\
2,9\end{array}$ & $\begin{array}{l}- \\
1,3 / \\
1,2\end{array}$ & $\begin{array}{l}8,9 / \\
6,2\end{array}$ & $\begin{array}{c}26,7 / \\
23,9\end{array}$ & $\begin{array}{l}\text { Key industries: agriculture, metallurgy, services. } \\
\text { Major companies: NEK EAD, Bulgarian } \\
\text { Telecommunications Company EAD, Kozloduy NPP } \\
\text { EAD. }\end{array}$ \\
\hline Great Britain & $\begin{array}{l}1,8 / \\
1,4\end{array}$ & $\begin{array}{c}0,3 / \\
0,7\end{array}$ & $\begin{array}{l}0,7 / \\
2,7\end{array}$ & $\begin{array}{c}4,9 / \\
4,4\end{array}$ & $\begin{array}{l}92,2 / \\
87,5\end{array}$ & $\begin{array}{l}\text { Key industries: services (banking, insurance, } \\
\text { brokerage, advisory), mining, manufacturing, } \\
\text { construction, agriculture, etc. Major companies: } \\
\text { British Petroleum, Cadbury plc, Ernst \& Young, } \\
\text { HSBC Holdings plc, Vodafone Group, Virgin Group, } \\
\text { etc. }\end{array}$ \\
\hline Hungary & $\begin{array}{c}2,2 / \\
4,0\end{array}$ & $\begin{array}{l}3,3 / \\
3,4\end{array}$ & $\begin{array}{l}0,4 / \\
2,4\end{array}$ & $\begin{array}{l}6,6 / \\
4,2\end{array}$ & $\begin{array}{c}75,1 / \\
73,6\end{array}$ & $\begin{array}{l}\text { Key industries: mechanical engineering, agriculture } \\
\text { (horticulture and viticulture), metallurgy, textile, food } \\
\text { industry, pharmaceuticals, services, etc. Major } \\
\text { companies: MOL (Magyar Olaj és Gázipari } \\
\text { Részvénytársaság), OTP Group, etc. }\end{array}$ \\
\hline Germany & $\begin{array}{c}2,2 / \\
1,9\end{array}$ & $\begin{array}{l}1,5 / \\
1,9\end{array}$ & $\begin{array}{c}0,4 / \\
1,7\end{array}$ & $\begin{array}{c}4,3 / \\
3,8\end{array}$ & $\begin{array}{l}69,0 / \\
63,9\end{array}$ & $\begin{array}{l}\text { Key industries: services, high technology, heavy and } \\
\text { light industry, agriculture. Major companies: BASF, } \\
\text { Bayer AG, BMW AG, Benteler AG, Robert Bosch } \\
\text { GmbH, Continental AG, Daimler AG, Deutsche Post } \\
\text { AG, Deutsche Telekom, Hermle, etc. }\end{array}$ \\
\hline Greece & $\begin{array}{c}-0,2 / \\
2,0\end{array}$ & $\begin{array}{c}- \\
1,0 / \\
- \\
1,2\end{array}$ & $\begin{array}{c}0,0 / \\
1,1\end{array}$ & $\begin{array}{l}24,6 / \\
21,4\end{array}$ & $\begin{array}{l}181,6 / \\
181,8\end{array}$ & $\begin{array}{l}\text { Key industries: the services sector (banking, } \\
\text { insurance, tourism), agriculture (horticulture and } \\
\text { vegetable growing), light and food industries, } \\
\text { petrochemical, woodworking, shipping, etc. Largest }\end{array}$ \\
\hline
\end{tabular}




\begin{tabular}{|c|c|c|c|c|c|c|}
\hline & & & & & & 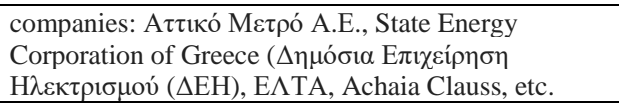 \\
\hline Denmark & $\begin{array}{l}2,0 / \\
2,0\end{array}$ & $\begin{array}{c}0,8 / \\
0,9\end{array}$ & $\begin{array}{c}0,3 / \\
1,1\end{array}$ & $\begin{array}{l}4,2 / \\
5,7\end{array}$ & $\begin{array}{l}39,6 / \\
35,3\end{array}$ & $\begin{array}{l}\text { Key industries: services, chemical industry, } \\
\text { shipbuilding, construction, electronics, } \\
\text { pharmaceuticals, agriculture, fisheries, etc. Major } \\
\text { companies: Arla Foods, FLSmidth, Grundfos, Bang \& } \\
\text { Olufsen (B\&O), Copenhagen Suborbitals, etc. }\end{array}$ \\
\hline Ireland & $\begin{array}{c}4,9 / \\
4,7\end{array}$ & $\begin{array}{l}1,2 / \\
1,4\end{array}$ & $\begin{array}{c}- \\
0,2 / \\
0,3 \\
\end{array}$ & $\begin{array}{l}8,0 / \\
6,7\end{array}$ & $\begin{array}{c}77,9 / \\
68,6\end{array}$ & $\begin{array}{l}\text { Key industries: services, renewable energy, construction, } \\
\text { agriculture, etc. Major companies: Accenture, Ingersoll- } \\
\text { Rand, CRH Plc., Airtricity Limited, etc. }\end{array}$ \\
\hline Spain & $\begin{array}{l}3,2 / \\
2,7\end{array}$ & $\begin{array}{l}2,0 / \\
2,2\end{array}$ & $\begin{array}{l}- \\
0,2 / \\
2,0\end{array}$ & $\begin{array}{c}19,7 / \\
17,2\end{array}$ & $\begin{array}{l}99,6 / \\
98,4\end{array}$ & $\begin{array}{l}\text { Key industries: services, engineering, shipbuilding, } \\
\text { construction, chemical industry, meat industry, light } \\
\text { industry, agriculture (crop production, viticulture, } \\
\text { vegetable growing). Largest companies: Gestamp } \\
\text { Automoción, Telefónica S.A., Abertis } \\
\text { Infraestructuras, Acciona, etc. }\end{array}$ \\
\hline Italy & $\begin{array}{c}0,9 / \\
1,2\end{array}$ & $\begin{array}{c}0,8 / \\
1,0\end{array}$ & $\begin{array}{c}- \\
0,1 / \\
1,3 \\
\end{array}$ & $\begin{array}{l}11,4 / \\
11,3\end{array}$ & $\begin{array}{c}132,5 / \\
131,8\end{array}$ & $\begin{array}{l}\text { Key industries: services (tourism, financial services, } \\
\text { transportation services, etc.). Major companies: } \\
\text { Benetton Group SpA, FIAT Group, Iveco, Eni Group. }\end{array}$ \\
\hline Cyprus & $\begin{array}{c}3,4 / \\
4,0\end{array}$ & $\begin{array}{l}1,5 / \\
1,7\end{array}$ & $\begin{array}{l}- \\
1,2 / \\
0,7\end{array}$ & $\begin{array}{l}11,8 / \\
11,1\end{array}$ & $\begin{array}{c}104,6 / \\
97,5\end{array}$ & $\begin{array}{l}\text { Key industries: services (tourism, financial services, } \\
\text { etc.), products of the processing industry, machinery } \\
\text { and equipment, metals and products of the chemical } \\
\text { industry. Small and medium-sized enterprises } \\
\text { predominate, incl. KEO }\end{array}$ \\
\hline Latvia & $\begin{array}{l}2,2 / \\
3,7\end{array}$ & $\begin{array}{l}2,6 / \\
2,8\end{array}$ & $\begin{array}{l}0,1 / \\
2,9\end{array}$ & $\begin{array}{l}9,6 / \\
8,7\end{array}$ & $\begin{array}{l}38,4 / \\
36,3\end{array}$ & $\begin{array}{l}\text { Key industries: electrical machines and equipment, } \\
\text { mechanical devices, nuclear reactors, land transport except } \\
\text { for railway or tram etc. Major companies: Latvenergo, Shot } \\
\text { factory (Daugavpils), etc. }\end{array}$ \\
\hline Lithuania & $\begin{array}{l}2,3 / \\
3,5\end{array}$ & $\begin{array}{l}3,3 / \\
3,5\end{array}$ & $\begin{array}{l}0,7 / \\
3,7\end{array}$ & $\begin{array}{l}8,2 / \\
7,1\end{array}$ & $\begin{array}{c}41,8 / \\
39,7\end{array}$ & $\begin{array}{l}\text { Key industries: agriculture, heavy and light industry, } \\
\text { services (transport services, travel services, } \\
\text { information technology). Small and medium-sized } \\
\text { enterprises predominate, including Kesko Senukai, } \\
\text { Viciunai Grou, ELTA, etc. }\end{array}$ \\
\hline Luxembourg & $\begin{array}{c}3,1 / \\
4,0\end{array}$ & $\begin{array}{l}1,7 / \\
1,6\end{array}$ & $\begin{array}{l}0,0 / \\
2,1\end{array}$ & $\begin{array}{l}6,7 / \\
5,8\end{array}$ & $\begin{array}{l}21,4 / \\
22,9\end{array}$ & $\begin{array}{l}\text { Key industries: services (trade, financial, tourism, insurance, } \\
\text { etc.), agriculture (meat and dairy cattle breeding, gardening, } \\
\text { viticulture). Major companies: Regus, ArcelorMittal, } \\
\text { Chemins de Fer Luxembourgeois, Luxlait, POST } \\
\text { Luxembourg, Radio Télévision Luxembourg, etc. }\end{array}$ \\
\hline Malta & $\begin{array}{c}5,2 / \\
5,7\end{array}$ & $\begin{array}{c}0,0 / \\
0,4\end{array}$ & $\begin{array}{c}0,9 / \\
1,3\end{array}$ & $\begin{array}{l}4,6 / \\
4,6\end{array}$ & $\begin{array}{c}62,6 / \\
50,7\end{array}$ & $\begin{array}{l}\text { Key industries: tourism, microchip manufacturing, } \\
\text { aircraft maintenance, programming, etc. Mostly small } \\
\text { and medium-sized companies dominate, including } \\
\text { GFI Software, etc. }\end{array}$ \\
\hline Netherlands & $\begin{array}{l}2,2 / \\
2,8\end{array}$ & $\begin{array}{l}1,1 / \\
1,0\end{array}$ & $\begin{array}{c}0,1 / \\
1,3\end{array}$ & $\begin{array}{l}6,2 / \\
4,9\end{array}$ & $\begin{array}{l}63,7 / \\
56,5\end{array}$ & $\begin{array}{l}\text { Key industries: heavy and light industry, the services } \\
\text { sector (tourism, financial, transport, etc.). Major } \\
\text { companies: Campina, Heineken, IKEA International } \\
\text { Group, Koninklijke Philips N.V. etc. }\end{array}$ \\
\hline Poland & $\begin{array}{c}3,1 / \\
4,4\end{array}$ & $\begin{array}{c}4,2 / \\
4,6\end{array}$ & $\begin{array}{l}- \\
0,6 / \\
2,0\end{array}$ & $\begin{array}{l}6,2 / \\
4,9\end{array}$ & $\begin{array}{c}54,2 / \\
50,6\end{array}$ & $\begin{array}{l}\text { Key industries: mechanical engineering, textile industry, } \\
\text { chemical industry, coal industry, ferrous metallurgy, } \\
\text { electronics manufacturing, services. Major companies: Polski } \\
\text { Holding Obronny, Grupa Azoty "Puławy", Fabryka Broni } \\
\text { "Lucznik", etc. }\end{array}$ \\
\hline Portugal & $\begin{array}{l}1,6 / \\
2,3\end{array}$ & $\begin{array}{c}0,9 / \\
1,0\end{array}$ & $\begin{array}{c}0,6 / \\
1,6\end{array}$ & $\begin{array}{c}11,3 / \\
8,9\end{array}$ & $\begin{array}{l}126,2 / \\
125,7\end{array}$ & $\begin{array}{l}\text { Key industries: mining, engineering, chemical and } \\
\text { petrochemical, agriculture (viticulture, fruit growing, } \\
\text { olive stands). Major companies: Aero VIP, EuroAtlantic } \\
\text { Airways, Hi Fly, Banco Comercial Português, Bial, etc. }\end{array}$ \\
\hline Romania & $\begin{array}{c}4,8 / \\
4,0\end{array}$ & $\begin{array}{l}2,0 / \\
2,2\end{array}$ & $\begin{array}{c}- \\
1,6 / \\
1,3\end{array}$ & $\begin{array}{l}6,7 / \\
4,9\end{array}$ & $\begin{array}{l}39,3 / \\
36,8\end{array}$ & $\begin{array}{l}\text { Key industries: oil industry, oil refining, metallurgical, } \\
\text { mechanical engineering, agriculture (viticulture, } \\
\text { horticulture, livestock, etc.), services. Major companies: } \\
\text { Bitdefender, Poşta Română SA, etc. }\end{array}$ \\
\hline
\end{tabular}




\begin{tabular}{|c|c|c|c|c|c|c|}
\hline Slovakia & $\begin{array}{l}3,3 / \\
3,9\end{array}$ & $\begin{array}{l}4,3 / \\
4,7\end{array}$ & $\begin{array}{c}- \\
0,5 / \\
1,3\end{array}$ & $\begin{array}{l}9,8 / \\
8,1\end{array}$ & $\begin{array}{l}52,4 / \\
50,9\end{array}$ & $\begin{array}{l}\text { Key industries: manufacturing, agriculture (animal } \\
\text { husbandry, crop production, viticulture, vegetable } \\
\text { growing). The services sector is presented mostly by } \\
\text { tourism. Major companies: U. S. Steel Košice, } \\
\text { Slovnaft. }\end{array}$ \\
\hline Slovenia & $\begin{array}{l}3,1 / \\
4,5\end{array}$ & $\begin{array}{l}2,0 / \\
2,4\end{array}$ & $\begin{array}{c}- \\
0,1 / \\
1,4\end{array}$ & $\begin{array}{c}11,6 / \\
6,6\end{array}$ & $\begin{array}{l}81,8 / \\
73,6\end{array}$ & $\begin{array}{l}\text { Key industries: automotive, electronics, electrical } \\
\text { equipment, services (tourism, financial). Major } \\
\text { companies: Slovenske železnice, Akrapovič, etc. }\end{array}$ \\
\hline Finland & $\begin{array}{l}2,5 / \\
2,6\end{array}$ & $\begin{array}{l}0,8 / \\
0,9\end{array}$ & $\begin{array}{l}0,4 / \\
0,8\end{array}$ & $\begin{array}{l}9,1 / \\
8,5\end{array}$ & $\begin{array}{l}64,9 / \\
61,3\end{array}$ & $\begin{array}{l}\text { Key industries: metallurgy, engineering, electronics, } \\
\text { agriculture (animal husbandry, vegetable growing, } \\
\text { etc.), services. Major companies: KWH Group, } \\
\text { Nokia, UPM-Kymmene Oyj, Stora Enso Oyj, etc. }\end{array}$ \\
\hline France & $\begin{array}{l}1,1 / \\
1,6\end{array}$ & $\begin{array}{l}1,0 / \\
0,9\end{array}$ & $\begin{array}{c}0,3 / \\
1,2\end{array}$ & $\begin{array}{l}9,7 / \\
9,4\end{array}$ & $\begin{array}{l}96,5 / \\
96,8\end{array}$ & $\begin{array}{l}\text { Key industries: mechanical engineering, chemical, } \\
\text { aerospace, food, electronics, agriculture (viticulture, } \\
\text { vegetable growing, animal husbandry, etc.), services. } \\
\text { Major companies: Airbus Group N. V., AXA Group, } \\
\text { Savencia Fromage \& Dairy, Bolloré, Danone, } \\
\text { Michelin, Groupe PSA, Schneider Electric, Valeo, } \\
\text { BNP Paribas, Société Générale, Crédit Agricole, etc. }\end{array}$ \\
\hline Croatia & $\begin{array}{l}3,5 / \\
2,8\end{array}$ & $\begin{array}{l}3,5 / \\
3,6\end{array}$ & $\begin{array}{c}- \\
1,1 / \\
1,1\end{array}$ & $\begin{array}{l}15,8 / \\
12,4\end{array}$ & $\begin{array}{l}88,3 / \\
77,8\end{array}$ & $\begin{array}{l}\text { Key industries: agriculture (fishing, forestry, } \\
\text { livestock, etc.), services (tourism, financial, trade). } \\
\text { Major companies: Podravka, Konzum, KONČAR } \\
\text { Group, Pliva, etc. }\end{array}$ \\
\hline $\begin{array}{l}\text { Czech } \\
\text { Republic }\end{array}$ & $\begin{array}{l}2,5 \\
3,1\end{array}$ & $\begin{array}{l}2,8 \\
3,4\end{array}$ & $\begin{array}{l}0,7 \\
2,4\end{array}$ & $\begin{array}{l}5,6 \\
2,9\end{array}$ & $\begin{array}{l}40,8 \\
34,7\end{array}$ & $\begin{array}{l}\text { Key industries: manufacturing, agriculture, services } \\
\text { (construction, transportation, financial, tourism, etc.). } \\
\text { Major companies: ŽD̃AS a.s., OEZ, MTH Hranice, } \\
\text { Inc. etc. }\end{array}$ \\
\hline Sweden & $\begin{array}{l}2,7 / \\
2,4\end{array}$ & $\begin{array}{l}4,2 / \\
4,4\end{array}$ & $\begin{array}{l}1,1 / \\
1,9\end{array}$ & $\begin{array}{l}6,9 / \\
6,7\end{array}$ & $\begin{array}{l}41,4 / \\
40,8\end{array}$ & $\begin{array}{l}\text { Key industries: services (transport, communications, } \\
\text { trade, tourism); industry. Major companies: Volvo } \\
\text { AB, Telia Company, Nordea Bank AB, etc. }\end{array}$ \\
\hline Estonia & $\begin{array}{l}1,5 / \\
3,7\end{array}$ & $\begin{array}{l}3,2 / \\
3,1\end{array}$ & $\begin{array}{l}0,8 / \\
3,7\end{array}$ & $\begin{array}{l}6,5 / \\
5,8\end{array}$ & $\begin{array}{c}9,7 / \\
9,0\end{array}$ & $\begin{array}{l}\text { Key industries: chemical, mechanical engineering, } \\
\text { agriculture (animal husbandry, crop production), } \\
\text { services (tourism and hospitality, transportation, } \\
\text { financial, etc.). Major companies: Nortal, MicroLink, } \\
\text { Harju Elekter, etc. }\end{array}$ \\
\hline
\end{tabular}

Source: Authors' research.

On this basis, we analyze the data for 2016 and 2018 indicating the dynamics of changes in the key figures of the European Union countries; GDP growth rates, industrial production, inflation, unemployment, national debt (as percentage of GDP). Based on the data presented in Table 1, countries of Southern Europe and certain countries of Central and Eastern Europe have the highest public debt. This means that loans provided by the International Monetary Fund (IMF) to individual states do not lead to stabilization of their economies. So, according to the data indicated in the Table, the unemployment rate in 2018 in Greece was 21.4\%, in Spain 17.2\%, in Croatia $12.4 \%$, in Italy $11.3 \%$, and in Cyprus $11,1 \%$. High unemployment also remains a feature of the Spanish model. Unemployment is exacerbated not only by the inflexibility of admission, dismissal and wages, but also by the adverse conditions in the country for employers in terms of long periods, the cost of starting a business, significant government intervention in enterprises, difficulties in obtaining a loan, etc.

According to statistics, only some countries of Eurozone have slightly changed or even reduced the unemployment rates. In the Netherlands, the unemployment rate in 2016 was $6.2 \%$, and in $20184.9 \%$, in Belgium 8.4\% and 7.1\%, respectively, in 
Luxembourg $6.7 \%$ and $5.8 \%$, in Ireland, $8.0 \%$ and $6.7 \%$. If we take the individual countries of Central and Eastern Europe that are part of Eurozone, in Latvia the unemployment rate in 2018 was $8.7 \%$, in Lithuania $7.1 \%$, Slovakia $8.1 \%$, Slovenia $6.6 \%$. In general, in terms of employment, Eurozone is inferior to the European Union. Throughout the entire study period, unemployment in Eurozone was higher than in the EU.

The change in the debt burden of the EU member states is also presented in Table 1. It is necessary to note individual countries of the South, for which public debt exceeds $100 \%$ of GDP. In 2018, the following countries had a public debt over $100 \%$ of their GDP: Greece (181.8\% of GDP), Italy (131.8\%), Portugal (125.7\%), Belgium (103.4\% of GDP). The general trend is that Eurozone is rapidly increasing national debt and does not apply significant measures to reduce them. Basically, the practical actions of the leadership of member countries to reduce national debt is local in nature. In addition, forecast estimates show an increase in the debt burden in most countries of Eurozone. So, Belgium, Greece, Italy, Portugal, and other countries go beyond $100 \%$ of GDP. However, it is necessary to emphasize that the growth of sovereign debt of Eurozone countries is a consequence, not the cause of the crisis. Therefore, it is necessary to analyze the causes of problems and contradictions that exist in the integration group, and not their consequences.

As for inflation in the countries of the European Union, it is relatively low everywhere. In 2018, the highest inflation is observed in Lithuania 3.7\%. The lowest inflation rate is in Ireland (0.3\%), Cyprus (0.7\%), Finland (0.8\%), Denmark (1.1\%), Croatia $(1.1 \%)$, Bulgaria (1.2\%), and Italy (1.3\%). In general, inflation in Eurozone fell in March 2019 to the lowest level since the introduction of the euro currency and amounted to $0.6 \%$. The main reason for this process is the drop in energy prices. Without this decrease, inflation would be $1.6 \%$, which is also considered a sign of price stability. A further slowdown in inflation is expected in Germany, the largest Eurozone economy. This is evidenced by the sharpest drop in wholesale prices over the past 20 years.

As of GDP growth rates in the European Union countries, the European Commission at the beginning of 2019 sharply lowered its forecast for Eurozone GDP growth in the current and next year due to an unexpected slowdown in the expansion of the largest economies of the bloc, caused by tensions in world trade and an increase in public debt. The German economy, the largest in the bloc, slowed growth to $1.9 \%$ in 2018 compared with the previous year by $0.4 \%$. The GDP growth rates of Great Britain, Spain, Romania, Croatia are also slowing down; 1.4\%, 2.7\%, 4.0\%, 2.8\% respectively. Slight GDP growth is observed in Austria 2.8\%, Hungary $4.0 \%$, Italy $1.2 \%$, The Netherlands $2.8 \%$. in Poland 4.4\%, in the Czech Republic 3.1\%. The development of industrial production shows that in the European Union economic growth is gradually starting again, but in different countries the rate of this growth is different. In some countries, such as France $(0.9 \%)$, the Netherlands $(1.0 \%)$ and Estonia $(3.1 \%)$, 
industrial production is declining, while in Poland (4.6\%) and the Czech Republic $(3,4 \%)$ an increase is spotted.

In addition, Table 1 shows the large companies of the countries of the European Union. A special threat to the economic sovereignty of developing countries, in addition to international economic organizations and various associations, is provided by transnational corporations (TNCs) and transnational banks (TNBs) of developed countries of the integration group. We single out the countries of the South and CEE since the negative effect of trade and economic interaction with TNCs of developed countries is especially noticeable there. It should be noted that initially almost all the large enterprises of the CEE and South countries lose the competition in the common European market with the largest transnational corporations of Western European countries. Even judging by the criteria established by Forbes regarding the rating of the largest transnational corporations in the world, namely on the basis of revenue, profit, assets and market capitalization, we can say with confidence that at least one hundred companies from CEE or South countries are not represented. This fact does not allow the represented countries to be active actors in the European market. In the current conditions not only transforms their sectoral structure towards the degradation of key sectors, but also causes an increase in unemployment, as well as an impressive migration of the population in search of a higher-paying and prestigious job in the developed EU countries.

Analyzing the key macroeconomic indicators of the European Union member states and identifying the key problems of the countries of the South and Central-Eastern Europe, we propose applying two fundamental approaches, the horizontal and the sectoral (by industry) in order to eliminate economic inequality between the partner countries of the integration group. As for the horizontal approach, it applies to all countries - members of the European Union and serves as a vector of socio-economic development of the integration. In addition, it is necessary to apply universal measures of foreign economic cooperation that do not infringe on the national sovereignty and interests of countries (for example, the participation of foreign capital in the country, the protection of uncompetitive enterprises by the state, etc.).

In addition, it is necessary to apply a sectoral (industrial) approach in foreign economic relations. So far, we propose to divide the European Union into four industry clusters. Each of these clusters has distinct leaders. In the first cluster is Germany and France; in the second cluster the leading country is Italy; in the third cluster the leading countries are Poland and the Czech Republic; in the fourth cluster is Sweden. In some of them, formal and informal unions have already formed (Benelux, Visegrad Four, Northern Council). In addition, we focus on the industry specialization of the leader, on its position in the microregion, on its strategic guidelines in economic development, etc. These centers will become a kind of 'gravitational field'. Each of these clusters has a specific industry specialization. 
Figure 1. The application of a horizontal and sectoral approach in foreign economic relations between the countries of the European Union.

\author{
Applying a horizontal and sectoral approach \\ in foreign economic relations between the EU countries
}

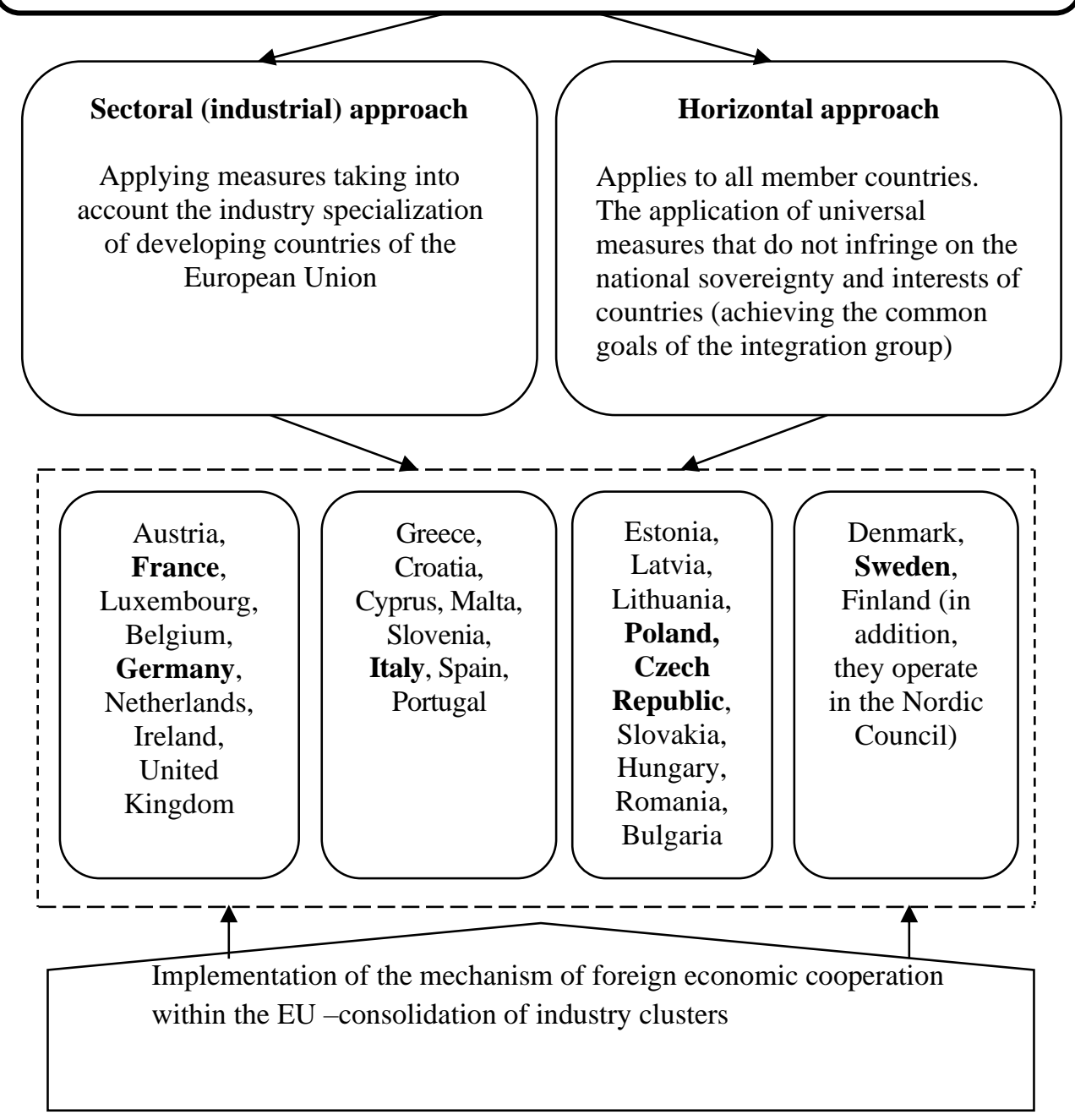

Source: Compiled by the authors.

We focus on the fact that peripheral countries should become full participants in foreign economic and foreign trade relations, and not an appendage for Vanguard countries. The four industry clusters presented in Figure 1 will make it possible to eliminate the existing inequality between the countries of the Vanguard and the periphery in modern conditions. If these measures are not implemented in the short or medium term, further transformation of the European Union cannot be avoided. 


\section{Discussion}

In this regard, the question arises is do forms of interaction, including integration, provide conditions for reducing the economic gap between developing and developed countries? In general, the process of reducing the backlog suggests that unification between partner countries will bring more benefits to developing countries than postindustrial ones. Notable that the neoclassical theory of factors of production involves the process of unification of countries in the region where integration processes are carried out. According to this theory, in industrialized countries participating in integration, there is an extremely low return on capital and the highest possible labor productivity. Consequently, real wages are high.

On the contrary, developing countries participating in integration are characterized by extremely high profitability of capital, extremely low labor productivity and low wages. Under these conditions, the dynamics of factors lead to the erasure of intraregional differences in incomes. Without applying the neoclassical theory of foreign trade and economic growth, one can build models that, due to the integration of postindustrial countries and developing countries, will lead to greater imbalances rather than convergence. The most significant of them can be distinguished as capital moves from developing countries to developed ones, and not vice versa. Integration processes lead to the outflow of highly qualified specialists ("brain drain") and the loss of growth potential; participation in association with developed countries obliges developing countries to carry out reforms, the results of which can be extremely unexpected. However, world experience shows that both a polarization process and convergence are possible in the case of regional integration of developed and developing countries.

\section{Conclusions}

The article analyzes the dynamics of unemployment, inflation, public debt, GDP growth rates, industrial production growth rates in the European Union member countries. The features of foreign economic relations of the member countries of the European Union, as well as the problems and contradictions of their international relations are identified. Two approaches are proposed in terms of foreign economic cooperation between the countries of the European Union, horizontal and sectoral (industry), four industry clusters are distinguished in the European Union, each of which has distinct leaders.

\section{References:}

Balassa, B. 1982. The Theory of Economic Integration. Greenwood Press.

CIS\&EU. 2018. Foreign Trade of the CIS and EU countries. Pocketbook, Interstate Statistical Committee of the CIS.

Ereport. 2020. World Economy Figures. Available at: http://www.ereport.ru/stat.php?razdel=country. 
Eurostat. 2020. European statistics. Available at: http://ec.europa.eu/eurostat/publications/statistical-books.

Frank, A.G. 1980. Crisis in the world economy. Holmes and Meier Publishers.

Galbraith, J.K. 1951. Conditions for Economic Change in Underdeveloped Countries. American Journal of Agricultural Economics, Agricultural and Applied Economics Association, 33(4P2), 689-696.

Gazol Sanchez, A. 1966. Industrial complementation and economic integration: The case of the A.L.A.L.C. Libros SELA, Mexico.

Malakhova, T.S. 2015. The crisis of the global economy: trends and contradictions. Krasnodar, Kuban State University, 79-80.

Malakhova, T.S., Dubinina, M.A., Maksaev, A.A, Fomin, R.V. 2019. Foreign Trade and Marketing Processes in the Context of Sustainable Development. International Journal of Economics and Business Administration, S2.

Malakhova, T.S., Kolesnikov, N.P. 2019. Trends and contradictions of the global economy crisis and transformation of the world financial institutions. European Journal of Economics and Management Sciences, 1, 38-41.

Myrdal, G. 1956. An International Economy: Problems and Prospects. Harper \& brothers' publishers, New York.

Nehru, J. 1961. Strategy of the Third Plan. Problems in the Third Plan: A Critical Miscellany. Delhi.

Pazos, F. 1953. Economic Development and Financial Stability. Staff Papers, International Monetary Fund, WDC.

Prebish, R. 1981. Peripheral capitalism: crisis and transformation. Mexico.

Tinbergen, J. 1952. On the Theory of Economic Integration. Les Cahiers de Bruges, Bruges Quarterly.

Viner, J. 1953. International Trade and Economic Development. Oxford, Clarendon Press, 7.

Williams, J.H. 1953. Economic Stability in a Changing World. Oxford University Press. 